\title{
Electron Microscopy of Clay Minerals in Mudrocks from the San Andreas Fault Observatory at Depth (SAFOD)
}

\author{
by Anja M. Schleicher, Ben A. van der Pluijm, \\ Laurence N. Warr, and John G. Solum
}

doi:10.2204/iodp.sd.s01.33.2007

\section{Introduction}

The San Andreas Fault Observatory at Depth (SAFOD) drill site situated near Parkfield, California (Hickman et al., 2004) offers the opportunity to assess the interplay between clay formation, faulting, and fluid migration in an active fault zone through direct sampling from depth and comparison with exhumed fault strands (Chester et al., 2004; Evans and Chester, 1995; Solum and van der Pluijm, 2004). Recent electron microscopy and x-ray diffraction (XRD) studies of rock fragments and cuttings from this drill site show abundant clay minerals in the host rock, on fracture surfaces, and within mineralized veins (Schleicher et al., 2006; Solum et al., 2006). It is, therefore, of importance to determine the timing of clay formation in relation to pre-, syn-, or postfaulting activities, and to establish their influence on the seismic behavior of the San Andreas Fault (Wu, 1975). Within this context, the formation of clays at depth is a potential weakening mechanism of crustal-scale faults (Warr and Cox, 2001; Wintsch et al., 1995; Zoback, 2000).

In this study of mineral transformations, the scanning electron microscope (SEM) and transmission electron microscope (TEM) are used to provide new insights into the nano-scale characteristics of clay minerals, and to evaluate the mineralogical characteristics of very fine-grained particles in fault rocks from the SAFOD drill hole. Using high-resolution TEM, the following aspects are being investigated: i) the microstructural characteristics of the clay mineral phases down to the nanometer scale, ii) the clay polytype structures by selected-area diffraction analysis (SAED), iii) the microchemistry of clay particles using analytical electron microscopy (AEM) and elemental geochemistry (ICP), and iv) the hydration state of smectite using wet-cell XRD and TEM. Based on these investigations, different events of clay formation can be assessed in order to characterize diagenetic or hydrothermal fluid-driven growth processes.

\section{Sampling and Methods}

Fine-grained, clay-rich rock fragments up to $1 \mathrm{~cm}$ in average length were collected from a spot-core of a clay-rich shear zone at $3067 \mathrm{~m}$ measured depth (MD, upper star in Fig. 1). This part of the borehole represents a potentially active section of the San Andreas fault zone, although it is currently not considered to contain the main fault trace (Zoback et al., 2005). The samples show distinct polishing and striations on particle surfaces and on fracture surfaces. Some of these carefully washed rock chips were ultrasonically treated to remove surface particles and to study their nature.

Other rock fragments with similarly polished surfaces were found at $3436 \mathrm{~m} \mathrm{MD}$ from inside a core catcher after a failed coring attempt (lower star in Fig. 1). In an attempt to preserve the mineralogical structure, natural hydration state, and textural properties, specimens were bottled and embedded in resin directly on site. The travel-time of rockchips from the bottom of the hole to the surface is about 7.5 hours. The fractured core chips were cleaned of drilling mud using dry paper towels and placed into small sample bottles containing 50\% methanol and 50\% LR White resin. In the laboratory, the solvent was progressively removed by using increasing concentrations of LR White resin following the procedure of Kim et al. (1995). Polymerization was

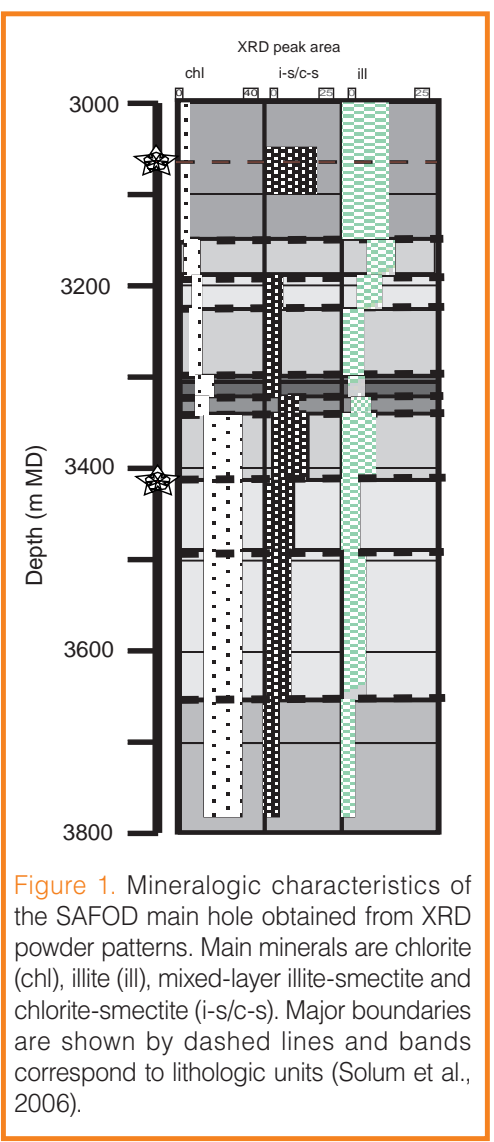
achieved by transferring to casting molds, and the bubbles were removed in a vacuum desiccator. Finally, the samples were hardened in a vacuum oven at $60^{\circ} \mathrm{C}$ for 24 h. Backup samples were stored in humidity-controlled vessels to avoid drying and any contact with liquid water.

SEM of thin sections prepared from the impregnated rock fragments allowed preselection of locations of interest that were subsequently investigated by TEM. Small $\mathrm{Cu}$-washers were glued on these areas and thinned using an ion mill apparatus. All 

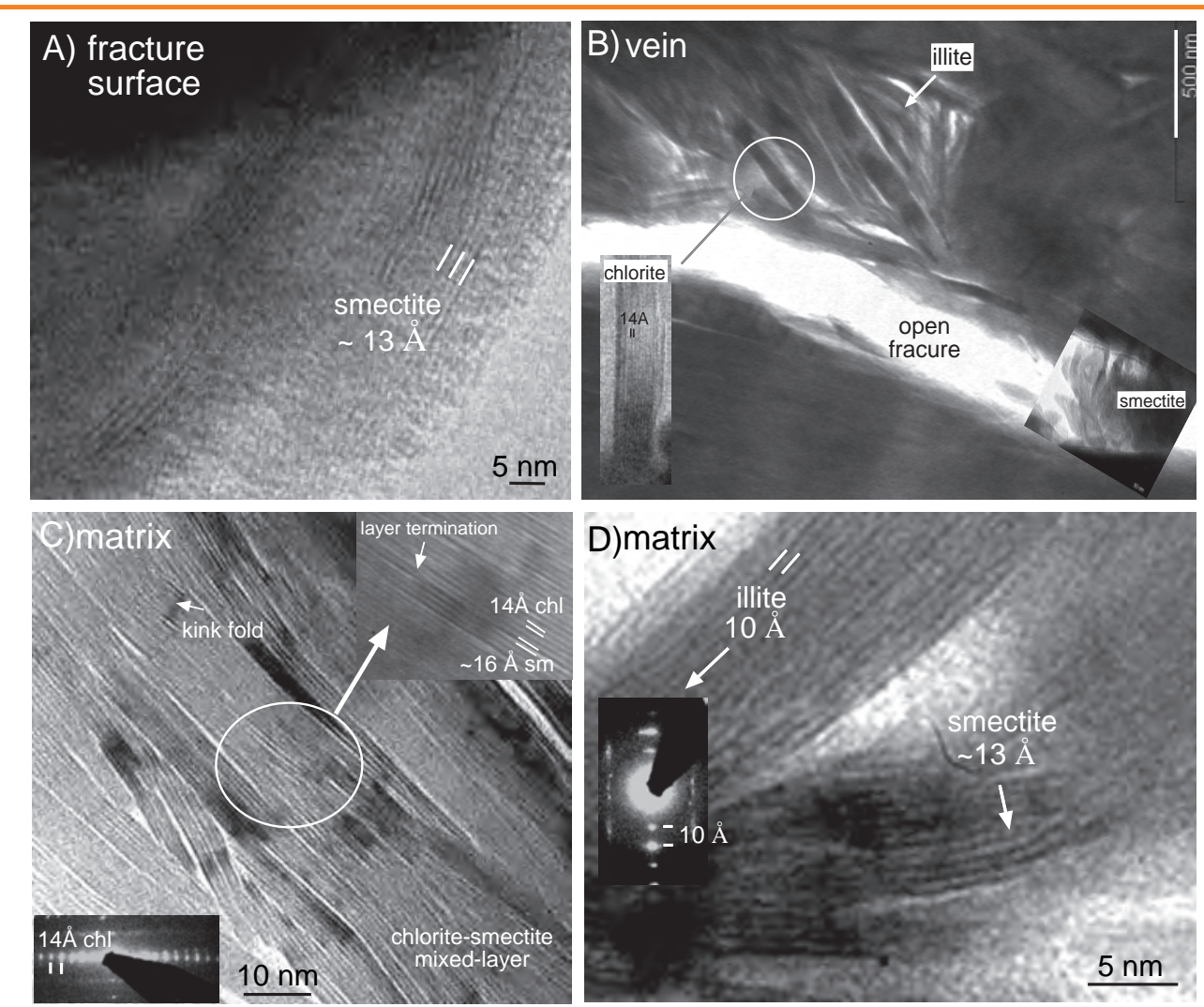

Figure 2. Low and high resolution TEM images of [A] smectite ultrasonically separated from fracture surfaces, [B] smectitic vein fillings that are surrounded by packets of chlorite and illite crystals, [C] rock-matrix samples with interstratifications of chlorite and smectite (note microstructures such as kink folds and layer terminations), and [D] packets of illite growth with illite-smectite mixed-layering and smectite.

electron microscopy work was conducted in the EMAL at the University of Michigan, using the methods described in Warr and Nieto (1998). Microscopy was undertaken using a Philips CM12 scanning transmission electron microscope at an operating voltage of $120 \mathrm{kV}$ and a beam current of $20 \mu \mathrm{A}$. High-resolution imaging was conducted at magnifications between 50,000x and 350,000x. Chemical analysis was performed in scanning mode by energy-dispersive spectrometry analysis over areas of $100 \mathrm{~nm}^{2}$ using a Kevex Quantum solid-state detector.

\section{Results and Ongoing Work}

At least three different structural types of smectiteoccurence could be distinguished in the SAFOD mud-rock fragments: i) fracture surfaces with thin films and slickenfibers (Fig. 2A, Schleicher et al., 2006), ii) vein mineralization in the rock matrix (Fig. 2B), and iii) the matrix containing chlorite, smectite, chlorite-smectite, and illitesmectite mixed-layerings (Figs. 2C and 2D). The thin films that cover the fracture surfaces at $3067 \mathrm{~m}$ and $3436 \mathrm{~m} \mathrm{MD}$ reveal smectitic aluminosilicate minerals with a variable cation content of $\mathrm{Na}, \mathrm{K}, \mathrm{Ca}, \mathrm{Mg}$, and $\mathrm{Fe}$. These compositions differ from the smectite minerals of the fresh drilling mud. A smectite phase with a composition similar to the fracture coatings was detected in the mineralized veins at $3436 \mathrm{~m}$ MD. Here, chlorite and illite crystals occur as mixed- layerings together with a discrete smectite phase covering the margins of the veins.

In contrast, the matrix shows small areas with discrete smectite phases; however, most smectites occur as mixed-layers of illite-smectite and chloritesmectite. They usually occur together with large packets of illite and chlorite. SEM investigations of these minerals reveal large irregular detrital grains with curved and damaged particle shapes. They are surrounded by a compacted fabric (presumably bedding parallel), perpendicular to the polished fractures and containing notably higher concentrations of $\mathrm{K}, \mathrm{Mg}$, and Fe. Illite, chlorite, and interstratifications of smectite with chlorite and illite have also been recognized by Solum et al. (2006) in the whole-rock XRD patterns. Based on first analysis of illite diffraction patterns (SAED), ordered and disordered $1 \mathrm{M}$ polytypes can be distinguished, whereas a highertemperature $2 \mathrm{M}_{1}$ illite polytype has not yet been recognized.

Preliminary observations of samples impregnated on site also indicate the coexistence of authigenic illite-smectite and discrete smectite particles that were not disturbed during embedding and polymerization. However, the characterization of microstructures and comparison with non-impregnated material are not yet fully determined and require more detailed study.

\section{Discussion}

Based on the ongoing electron microscopy study of SAFOD drill rocks, illite, chlorite, and smectite in combination with diverse mixed-layered minerals occur in the argillaceous lithologies. However, the TEM analysis in particular shows that the minerals were formed in texturally different microstructural sites, suggesting different formation processes.

Among the key observations is a natural smectite phase on the fracture surfaces that occurs as oriented platy and fibrous minerals, forming thin film coatings with slickenfibers (Fig. 2A). This clay phase is interpreted as an authigenic phase formed by dissolution-precipitation reactions 
during the movement of aqueous fluids along permeable fractures and veins at temperatures possibly up to $\sim 130^{\circ} \mathrm{C}$ (Moore and Reynolds, 1997; Schleicher et al., 2006; Williams et al., 2005). The fibrous nature suggests fault creep as the environment for their formation, but the timing of initial fracture formation remains uncertain, so that the clay-films could also represent growth along reactivated faults structures.

The large packets of illite and chlorite in the matrix show curved and damaged particle shapes with kink bands and layer terminations (Fig. 2C) that occur together with smectitic mixed-layering. The ordered and disordered $1 \mathrm{M}$ illite polytypes, based on SAED patterns, reflect the likely transformation of illite-smectite to smectite in the diagenetic compaction processes. Such events are well known, for example, in argillite lithologies of the Salton Sea geothermal system (Yau et al., 1987) or the Gulf Coast (Freed and Peacor, 1992).

Further investigations will be necessary to detail specific mineral reactions and swelling behavior of clays at the crystal lattice scale. Particularly important is to determine the formation mechanisms (e.g., layer-by-layer replacement vs. dissolution and neocrystallization) and fabrics of the clays, and to establish the timing of reactions in relation to the deformation history of the fault rocks.

\section{Acknowledgements}

Our SAFOD research is supported by the EarthScope Program of the U.S. National Science Foundation (NSF) and by the Deutsche Forschungsgemeinschaft (DFG).

\section{References}

Chester, F.M., Chester, J.S., Kirschner, D.L., Schulz, S.E., and Evans, J.P., 2004. Structure of large-displacement, strike-slip fault zones in the brittle continental crust. In Karner, G.D., Taylor, B., Driscoll N., Kohlstedt D. (Eds.), Rheolgoy and Deformation in the Lithosphere at Continental Margins. New York (Columbia University Press), 223-260.

Evans, J.P. and Chester, F.M., 1995. Fluid-rock interaction in faults of the San Andreas system; inferences from San Gabriel Fault rock geochemistry and microstructures. J. Geophys. Res., 100:13007-13020, doi:10.1029/94JB02625.

Freed, R.L. and Peacor, D.R., 1992. Diagenesis and formation of authigenic illite-rich I/S crystals in Gulf Coast shales: TEM study of clay separates. J. Sediment. Petrol., 62:220-234.

Hickman, S., Zoback, M., and Ellsworth, W., 2004. Introduction to special section: Preparing for the San Andreas Fault Observatory at Depth. Geophys. Res. Lett., 31:L12S01, doi: 10.1029/2004GL020688.

Kim, J.W., Peacor, D.R., Tessier, D., and Elsass, F., 1995. A technique for maintaining texture and permanent expansion of smectite interlayers for TEM observations. Clays and Clay Minerals, 43:51-57, doi:10.1346/CCMN.1995.0430106.
Moore, D.W. and Reynolds, R.C. 1997. X-ray Diffraction and the Identification and Analysis of Clay Minerals, 2nd Edition. Oxford,U.K. (Oxford University Press).

Schleicher, A.M., van der Pluijm, B.A., Solum, J.G., and Warr, L.N., 2006. The origin and significance of clay minerals on surfaces, in fractures and in veins from SAFOD borehole samples (Parkfield, California). Geophys. Res. Lett., 33: L16313, doi:10.1029/2006GL026505.

Solum, J.G. and van der Pluijm, B.A., 2004. Phyllosilicate mineral assemblages of the SAFOD Pilot Hole and comparison with an exhumed segment of the San Andreas Fault System. Geophys. Res. Lett., 31:L15S19, doi:10.1029/2004GL01990.

Solum, J.G., Hickman, S.H., Lockner, D.A., Moore, D.E., van der Pluijm, B.A., Schleicher, A.M., and Evans, J.P., 2006. Mineralogical characterization of protolith and fault rocks from the SAFOD main hole. Geophys. Res. Lett., 33:L21314, doi:10.1029/2006GL027285.

Warr, L.N. and Cox, S., 2001. Clay mineral transformations and weakening mechanisms along the Alpine Fault, New Zealand. Geolog. Soc. Lond. Spec. Publ., 186:85-101.

Warr, L.N. and Nieto, F., 1998. Crystallite thickness and defect density of phyllosilicates in low-temperature metamorphic pelites: a TEM and XRD study of clay-minerals crystallin ity index standards. Canad. Min., 36:1453-1474.

Williams, C.F., D’Alessio, M.A., Grubb, F.V., and Galanis, S.P., 2005. Heat flow in the SAFOD main hole. Eos Trans. AGU, 86 (52), Fall Meet. Suppl., Abstract T23E-07.

Wintsch, R.P., Christoffersen, R., and Kronenberg, A., 1995. Fluidrock reaction weakening of fault zones. J. Geophys. Res., 100(B7):13021-13032.

Wu, F.T., Blatter, L., and Robertson, H., 1975. Clay gouges in the San Andreas Fault system and their possible implications. Pure Appl. Geophys., 113:87-96, doi:10.1007/BF01592901.

Yau, Y.-C., Peacor, D.R., and McDowell, D., 1987. Smectite-to-illite reactions in Salton Sea shales; a transmission and analytical electron microscopy study. J. Sediment. Res., 57:335-342.

Zoback, M.D., 2000. Strength of the San Andreas fault. Nature, 405:31-32.

Zoback, M.D., Hickman, S., and Ellsworth, W., 2005. Overview of SAFOD Phases 1 and 2: Drilling, sampling and measurements in the San Andreas Fault zone at seismogenic depth. Eos Trans. AGU, 86(52), Fall Meet. Suppl., Abstract T23E01.

\section{Authors}

Anja M. Schleicher, Universität Würzburg, Geologisches Institut, Pleicherwall 1, 97070 Würzburg, Germany, e-mail: aschleic@umich.edu.

Ben A. van der Pluijm, University of Michigan, Department of Geological Sciences, 1100 University Avenue, C.C.Little Building, Ann Arbor, Mich. 48109, U.S.A.

Laurence N. Warr, Centre de Géochimie de la Surface (CNRS-ULP), 1 rue Blessig, 67084 Strasbourg, France.

John G. Solum, U.S. Geological Survey, Earthquake Hazards Team, 345 Middlefield Road, MS 977 Menlo Park, Calif. 94025, U.S.A. 